\title{
Bacillus stamsii sp. nov., a facultatively anaerobic sugar degrader that is numerically dominant in freshwater lake sediment
}

\author{
Nicolai Müller*, Frank D. Scherag ${ }^{1}$, Michael Pester, Bernhard Schink \\ Department of Biology, University of Konstanz, 78457 Konstanz, Germany
}

Keywords:

Bacillus

Facultatively anaerobic metabolism

Syntrophic oxidation

Sugar fermentation

\begin{abstract}
A B S T R A C T
A novel type of anaerobic bacteria was previously isolated from profundal lake sediment by direct dilution of the sediment in mineral agar medium containing glucose and a background lawn of Methanospirillum hungatei as a syntrophic partner. The isolated bacteria grouped with aerobic Bacillus spp. according to their 16S rRNA gene sequence, and the most closely related species is Bacillus thioparans. Fermentative growth of the novel strain with glucose was possible only in the presence of syntrophic partners, and cocultures produced acetate and methane, in some cases also lactate and traces of succinate as fermentation products. In contrast, the closely related strains Bacillus jeotgali and Bacillus sp. strain PeC11 are able to grow with glucose axenically by mixed acid fermentation yielding lactate, acetate, formate, succinate, and ethanol as fermentation products. Alternatively, the isolated strain grew anaerobically in pure culture if pyruvate was added to glucose-containing media, and lactate, acetate and formate were the major fermentation products, but the strain never produced ethanol. Aerobic growth was found with a variety of organic substrates in the presence of partly reduced sulfur compounds. In the absence of sulfide and oxygen, nitrate served as an electron acceptor. Strain BoGlc83 was characterized as the type strain of a

new species for which the name Bacillus stamsii sp. nov. (DSM 19598=JCM 30025) is proposed.
\end{abstract}

\section{Introduction}

In a study on anaerobic saccharolytic bacteria in the profundal sediment of Lake Constance, Germany, we isolated a slow-growing, spore-forming bacterium which grew with glucose, fructose, and few other sugars only in syntrophic association with hydrogenor formate-oxidizing methanogenic partner organisms [18]. This bacterium depended on cooperation with a partner organism; inhibition of the methanogenic partner by bromoethane sulfonate prevented growth and substrate utilization completely. Phylogenetic analysis indicated that this new isolate is related to aerobic sporeformers of the genus Bacillus, most closely related to Bacillus jeotgali [18]. Growth tests indicated that our isolate strain BoGlc83 could also grow aerobically, however, aerobic growth was found only in complex growth media and was not easy to reproduce.

\footnotetext{
* Corresponding author. Tel.: +49 7531 883558; fax: +49 7531884047.

E-mail address: Nicolai.Mueller@uni-konstanz.de (N. Müller).

1 Present address: Laboratory for Chemistry and Physics of Interfaces CPI, Department of Microsystems Engineering - IMTEK, University of Freiburg, 79110 Georges-Köhler-Allee 103, Freiburg, Germany.
}

In the present study, the physiology of this new isolate is studied, together with a taxonomic description. Further, the physiology of closely related strains was investigated including Bacillus thioparus which was described in the meantime and is even closer related to strain BoGlc83 $[21,56]$. The species name $B$. thioparus was revised later and Bacillus thioparans was introduced instead [7]. Moreover, Bacillus sp. strain PeC11, an isolate from guts of beetle larvae, falls within the same group of Bacillus strains [10]. The latter strain can couple oxidation of e.g. glucose to Fe(III) reduction, while $B$. thioparus can grow lithoautotrophically on thiosulfate [10,21].

Our data show that Bacillus sp. BoGlc83 is a versatile organism able to grow aerobically and anaerobically with various organic substrates. Yet, in reducing media the substrate range is narrow and the strain depends on a methanogenic partner, thus accentuating its potential role as a specialized sugar-utilizing bacterium in sulfidic sediments of a freshwater lake.

\section{Materials and methods}

Origin of bacterial strains

Enrichment and isolation of strain BoGlc from profundal sediments of Lake Constance, Konstanz, Germany, were described earlier [18]. The strain was deposited at the German Collection 
of Microorganisms and Cell-Cultures (DSM 19598) and the Japan Collection of Microorganisms (JCM 30025). Methanospirillum hungatei strain M1h was from our own strain collection. B. jeotgali (DSM 18226) and Bacillus megaterium (DSM319) were purchased from the German Collection of Microorganisms and Cell-Cultures (DSMZ). B. thioparans strain BMP-1 (CECT 7196) was purchased from the Spanish Type Culture Collection (CECT). Bacillus sp. PeC11 was kindly provided by Sven Hobbie and Dr. Andreas Brune, Marburg, Germany.

\section{Cultivation conditions}

For aerobic growth, cultures were incubated in $10 \mathrm{ml}$ glass tubes with aluminum caps or in Erlenmeyer flasks with cotton stoppers on a shaker at $200 \mathrm{rpm}$ and $30^{\circ} \mathrm{C}$. All Bacillus strains used in this study were routinely cultivated in LB medium containing $10 \mathrm{~g} / \mathrm{l}$ Bacto tryptone, $5 \mathrm{~g} / \mathrm{l}$ yeast extract, $10 \mathrm{~g} / \mathrm{l} \mathrm{NaCl}$ and $10 \mathrm{mg} / 1 \mathrm{MnSO}_{4}$ for sporulation (modified DSMZ-medium No.1). This modification helped to increase reproducibility of aerobic growth.

For aerobic cultivation in defined medium, we used a freshwater minimal medium containing HEPES $(10 \mathrm{mM}), \mathrm{NaCl}(17.1 \mathrm{mM})$, $\mathrm{MgCl}_{2} \cdot 6 \mathrm{H}_{2} \mathrm{O}(2 \mathrm{mM}), \mathrm{NH}_{4} \mathrm{Cl}(4.7 \mathrm{mM})$, and $\mathrm{KCl}(6.7 \mathrm{mM})$. The basal medium was autoclaved at $121^{\circ} \mathrm{C}$ and $1 \mathrm{bar}$ overpressure for $20 \mathrm{~min}$. After cooling to room temperature, the following supplements were added to the medium from concentrated sterile stock solutions: $\mathrm{CaCl}_{2} \cdot 2 \mathrm{H}_{2} \mathrm{O}(1 \mathrm{mM}), \mathrm{K}-\mathrm{Na}$-phosphate buffer, $\mathrm{pH}$ $7.0(1 \mathrm{mM}), 7$-vitamin-solution (1×, after Widdel and Pfennig [53]), trace element solution SL13 (1×, after Widdel et al. [51] and Müller et al. [18]). Thiosulfate was added as sulfur source at concentrations between 2 and $10 \mathrm{mM}$. Glucose or other substrates were added at concentrations between 2 and $10 \mathrm{mM}$ from filter-sterilized stock solutions.

For testing the $\mathrm{pH}$ tolerance and optimum, the medium was buffered with a mixture of MES, HEPES, Tris and CHES (10 mM each) to cover a $\mathrm{pH}$ buffering range from $\mathrm{pH} 5.0$ to 9.5. The desired $\mathrm{pH}$ was adjusted by $\mathrm{HCl}$ or $\mathrm{NaOH}$ to the basal medium before autoclaving. Glucose was added at a concentration of $4 \mathrm{mM}$ and thiosulfate at $2 \mathrm{mM}$ for pH-tests.

Growth under anoxic, reducing conditions was tested in oxygenfree freshwater medium buffered with $30 \mathrm{mM}$ sodium bicarbonate plus $1 \mathrm{mM}$ sodium sulfide as reducing agent as described before $[18,51,52]$. Cultivation was done in $15-\mathrm{ml}$ or 25 -ml glass tubes sealed with butyl rubber stoppers that were rendered anoxic by flushing the headspace with a $\mathrm{N}_{2} / \mathrm{CO}_{2}$ mixture (80\%/20\%). Tubes were filled after autoclaving aseptically with anoxic media by means of $\mathrm{N}_{2}$-flushed syringes.

For cultivation of bacteria under anoxic, non-reducing conditions the same anoxic medium was used as mentioned above, but $\mathrm{Na}_{2} \mathrm{~S}$ was omitted and instead $2 \mathrm{mM} \mathrm{Na}_{2} \mathrm{SO}_{4}$ or $2 \mathrm{mM} \mathrm{Na}_{2} \mathrm{~S}_{2} \mathrm{O}_{3}$ was added as a sulfur source.

Substrates or supplements were added from anoxic stock solutions. These stock solutions were made anoxic by repeatedly stirring under vacuum and gassing with $100 \%$ nitrogen as reported before [18].

\section{Growth experiments}

Bacterial growth was monitored at $578 \mathrm{~nm}$ wavelength with a tube spectrophotometer (M107, Camspec Analytical instruments Ltd., Leeds, UK) measuring optical densities directly in culture tubes. When optical densities had to be measured in samples from larger culture vessels, a double-beam cuvette spectrophotometer (Uvicon 860, Kontron, Zurich, $\mathrm{CH}$ ) was used. Optical densities in anoxic, reduced media were measured by adding a few grains of sodium dithionite to the cuvettes to keep resazurine in its reduced and colorless state.
Growth was defined as an overall change in optical density $\Delta \mathrm{OD}_{578}$ of $\geq 0.1$. Turbidities of a final $\Delta \mathrm{OD}_{578}$ of $0.05-0.09$ were categorized as "poor growth". Lower values of $\Delta \mathrm{OD}_{578}$ were defined as "no growth". Cultures were inoculated to an initial $\mathrm{OD}_{578}$ of $0.005-0.05$, meaning that, with the definition of growth mentioned above, a $\Delta \mathrm{OD}_{578}$ of 0.1 corresponds to approximately 2-4 doublings.

\section{PCR of bacterial 16S rRNA genes and phylogenetic analysis}

DNA extraction, amplification, and analysis of the 16S rRNA genes as well as calculation of the phylogenetic tree were done as described earlier [18]. Primers used for amplification of bacterial 16S rRNA genes were 27F (5'-AGA GTT TGA TCC TGG CTC AG-3') [6] and 1492R (5'-TAC GGY TAC CTT GTT ACG ACT T-3') [50]. Primers specific for the 16S rRNA gene of Bacillus sp. BoGlc83 were constructed using the BioEdit software tool [9]. The 100 most similar gene sequences available on the NCBI-database (www. ncbi.nlm.nih.gov/) were used for comparison. The primers thus obtained were BoGlcfw (5'-CCT TGA CGG TAC CTG CCA GA-3') and BoGlcrev (5'-GGC TCC AAG GTT GCC CCT AG-3') and were used to amplify a 991 DNA fragment at an annealing temperature of $55^{\circ} \mathrm{C}$ as described earlier [18].

Since several new bacterial isolates closely related to Bacillus sp. BoGlc83 were described in the meantime, we created an updated phylogenetic tree using the previously published partial sequence of the $16 \mathrm{~S}$ rRNA gene of strain BoGlc 83 with a length of 1488 bp (accession number AY189804, [18]). Sequences of interest were manually selected and aligned with the SINA aligner [24]. The phylogenetic tree was calculated with 1358 unambiguously aligned nucleic acid positions using the maximum-likelihood method RAxML as implemented in the ARB 5.5 software package (http://www.arb-home.de, [15,41]). The non-redundant SSU Reference dataset Nr. 99 from the arb-silva homepage was used for phylogenetic analysis (http://www.arb-silva.de, [25]). Bootstrap support for the individual branches in the phylogenetic tree was calculated using 1000 bootstraps and the RAxML algorithm as implemented in ARB (http://www.arb-home.de, [15,41]).

Strain BoGlc83 was also identified using the EzTaxon server (http://www.ezbiocloud.net/eztaxon; [13]) on the basis of $16 \mathrm{~S}$ rRNA gene sequence data. For aligning sequence data not contained in the EzTaxon database, NCBI BLAST (http://blast.ncbi.nlm. nih.gov/Blast.cgi, [2]) was used.

\section{DNA-DNA hybridization}

DNA-DNA hybridization was carried out by Dr. Cathrin Spröer of the Identification Service of the DSMZ, Braunschweig. Germany.

\section{Analytical methods}

Glucose, pyruvate, succinate, lactate, formate, and ethanol were analyzed by HPLC using an Aminex HPX-87H ion-exchange column (BioRad, Munich, Germany) heated to $60^{\circ} \mathrm{C}$ with $5 \mathrm{mM} \mathrm{H}_{2} \mathrm{SO}_{4}$ as eluent at a flow rate of $0.6 \mathrm{ml} / \mathrm{min}$ supplied by a LC-10AT vp pump (Shimadzu, Munich, Germany). Samples were injected into the system with a 234 autoinjector (Gilson, Limburg-Offheim, Germany). The analysis time was 25 min per sample. Analytes were detected with a refraction index detector RID-10A (Shimadzu) and the data analyzed using the Shimadzu LC solution software. Samples were prepared as described elsewhere [18].

Nitrate, nitrite, sulfate, and sulfite were analyzed with an ion chromatography system using an LCA A14 anion exchange column (Sykam, Fürstenfeldbruck, Germany). The detection range was between 0.05 and $1 \mathrm{mM}$, therefore, samples were diluted 1:100 with water before measurement. 
Thiosulfate was quantified by cyanolysis in the presence of $\mathrm{Cu}^{2+}$ (modified after Nor and Tabatabai [20]). Samples were diluted in distilled water to a final volume of $900 \mu \mathrm{l}$ and in a concentration range of $10-400 \mu \mathrm{M}$. Then, $50 \mu \mathrm{l}$ of a $0.1 \mathrm{M} \mathrm{KCN}$ solution was added and the samples were incubated at room temperature for $5 \mathrm{~min}$. Thereafter, the samples were mixed with $50 \mu \mathrm{l}$ of a $50 \mathrm{mM}$ $\mathrm{CuCl}_{2}$ solution and incubated for further $5 \mathrm{~min}$ at room temperature to release $1 \mathrm{~mol}$ of $\mathrm{SCN}^{-}$per mole of $\mathrm{S}_{2} \mathrm{O}_{3}{ }^{2-}$. Last, $50 \mu 10.75 \mathrm{M}$ $\mathrm{Fe}\left(\mathrm{NO}_{3}\right)_{3}$ in $3 \mathrm{M} \mathrm{HNO}_{3}$ was added and after an additional incubation time of $2 \mathrm{~min}$, the resulting iron(III)cyanate was quantified by recording the absorbance at $460 \mathrm{~nm}$ in a U-1100 spectrophotometer (Hitachi, Tokyo, Japan) against a control assay mixture without thiosulfate. Calibration curves were run using NaSCN standards in a range of $10-400 \mu \mathrm{M}$ in a final volume of $1 \mathrm{ml}$ to which each $50 \mu \mathrm{l}$ $\mathrm{Fe}\left(\mathrm{NO}_{3}\right)_{3}$ in $3 \mathrm{M} \mathrm{HNO}_{3}$ was added.

Determination of intra- and extracellular elemental sulfur was done by melting elemental sulfur in samples from bacterial cultures at $90^{\circ} \mathrm{C}$ in the presence of $\mathrm{KCN}$ to yield $\mathrm{SCN}^{-}$(modified after Schedel and Trüper [30]). Samples of 50-100 $\mu$ l culture were mixed with $3 \mathrm{ml}$ of a $0.1 \mathrm{M} \mathrm{KCN}$ solution in $15 \mathrm{ml}$ plastic tubes and incubated for $20 \mathrm{~min}$ in a water bath heated to $90^{\circ} \mathrm{C}$. Samples were allowed to cool to room temperature and $6.95-6.90 \mathrm{ml}$ distilled water and $500 \mu \mathrm{l} 0.75 \mathrm{M} \mathrm{Fe}\left(\mathrm{NO}_{3}\right)_{3}$ in $3 \mathrm{M} \mathrm{HNO}_{3}$ were added. The absorbance was measured in plastic cuvettes at $460 \mathrm{~nm}$ in a U-1100 spectrophotometer (Hitachi, Tokyo, Japan) and concentrations of $\mathrm{SCN}^{-}$ were calculated using calibration curves with NaSCN as described above.

Sulfite was qualitatively detected using sulfite test paper No. 907 63 (Macherey-Nagel, Düren, Germany). Sulfate was assayed using the barium chloride method [43].

Analyses of respiratory quinones, polar lipids, and fatty acid composition were carried out by the Identification Service of the DSMZ and Dr. Brian Tindall, DSMZ, Braunschweig. Germany. Analysis of the $\mathrm{G}+\mathrm{C}$ content of genomic DNA was carried out by the Identification Service of the DSMZ and Dr. Peter Schumann, DSMZ, Braunschweig. Germany.

Oxidase was tested using oxidase test strips (Fluka) following the manufacturer's instructions. Presence of catalase was tested by dropwise adding a $3 \% \mathrm{H}_{2} \mathrm{O}_{2}$ solution to a colony on solid media or to cell suspensions dropped on a glass slide. The oxidase and catalase-negative Lactobacillus plantarum and the oxidase and catalase-positive Paracoccus denitrificans were used as reference strains.

\section{Chemicals}

All chemicals were of analytical or reagent grade quality and purchased from Sigma (Deisenhofen, Germany), Fluka (Neu-Ulm, Germany), Serva (Heidelberg, Germany), Boehringer (Mannheim, Germany), Eastman Kodak (Rochester, NY, USA), Merck (Darmstadt, Germany), and Pharmacia (Freiburg, Germany), gases were purchased from Messer-Griesheim (Darmstadt, Germany), and Sauerstoffwerke Friedrichshafen (Friedrichshafen, Germany).

\section{Results}

Quantification of sugar-degrading bacteria in Lake Constance sediments

Sugar-degrading bacteria were counted aerobically and anaerobically both in the presence and absence of $M$. hungatei as a partner. After incubation for 2-3 months, anaerobic glucose-degrading colonies were found up to a total of $3.8 \times 10^{7}$ cells $/ \mathrm{cm}^{3}$ sediment. Aerobic counts in defined freshwater medium with $2 \mathrm{mM}$ glucose as sole substrate yielded counts of $7.4 \times 10^{7} \mathrm{cfu} \mathrm{cm}^{-3}$. Colonies in the agar were often fluffy and, in the case of anaerobic growth, surrounded by colonies of the methanogenic partner organism [18]. Bacterial cells in the colonies in both cases were short rods, often with subterminal elliptical spores [18]. Controls by PCR analysis confirmed that in both cases the same type of bacteria was cultivated.

Occurrence of this type of bacteria in Lake Constance sediments was verified also by amplification of the 16S rRNA gene of Bacillus sp. BoGlc83 using primers specific for this strain. Direct amplification of the expected PCR fragment from DNA isolated from lake sediment was not successful. In another experiment, DNA was isolated from sediments taken at different water depths (littoral sediment and profundal sediments at $77 \mathrm{~m}$ and $145 \mathrm{~m}$ water depth) and used as template for unspecific 16S rRNA gene amplification. The resulting PCR product was used as template for another PCR with the primers specific for Bacillus sp. BoGlc83. This PCR yielded the expected 991 bp fragment of the Bacillus sp. BoGlc83 16S rRNA gene from all three samples (data not shown).

\section{Chemotaxonomic and phenotypic characterization of strain BoGlc83}

Upon aerobic cultivation in modified LB medium, strain BoGlc83 grew as short, irregular rods of 5-10 $\mu \mathrm{m}$ length and $0.5-0.8 \mu \mathrm{m}$ width. Chains of five or more cells were often observed, especially in the early exponential phase. The phylogenetically related strains B. thioparans, B. jeotgali, and Bacillus sp. PeC11 were slightly shorter and thinner. Strain BoGlc83 belongs to the genus $B$. according to previous 16S-rRNA gene analyses [18]. Its closest described relatives are B. thioparans (similarity 98.91\% [21]), Bacillus subterraneus (similarity 98.51\% [12]), B. jeotgali (similarity 98.44\% [56]), Bacillus boroniphilus (similarity 98.31\% [1]), and Bacillus selenatarsenatis (similarity 98.30\% [54]) after analyzing the 16S rRNA gene sequence of Bacillus strain BoGlc83 using the EzTaxon Identify tool [13]. In addition, the 16S rRNA gene sequence of Bacillus strain BoGlc83 was aligned with the 16S rRNA gene sequence of the taxonomically undescribed Bacillus sp. PeC11 [10] using the BLAST bl2seq tool and the similarity was $98.1 \%$. The phylogenetic distance tree of Bacillus strain BoGlc83 and its closely related strains based on the 16S rRNA gene sequence is shown in Fig. 1. Based on the threshold value of $98.7 \%$ for differentiating two bacterial species by their 165 rRNA gene sequence $[28,39,55]$ Bacillus sp. BoGlc83 and $B$. thioparans seemed to represent the same species. Therefore, DNA-DNA hybridization of these two strains was performed and the DNA-DNA similarity was determined to be $23.8 \%$ and $25.5 \%$ in duplicate measurements. Considering that the DNA-DNA similarity of two strains must be smaller than $70 \%$ for classifying them as different species [49], we state that Bacillus sp. BoGlc83 and B. thioparans have to be grouped in two distinct species.

Strain BoGlc83 was oxidase positive but was catalase negative when tested after aerobic or anaerobic growth. The $\mathrm{G}+\mathrm{C}$ content was determined to $42.8 \mathrm{~mol} \%$ (Table 4 ). Respiratory quinones were menaquinone-7 (MK-7, 97\%) and menaquinone-6 (MK-6, $3 \%$ ). The strain contains the polar lipids diphosphatidylglycerol, phosphatidylglycerol and phosphatidylethanolamine as judged by thin-layer chromatography carried out by the DSMZ identification service. Analysis of the fatty acid composition classifies it as a member of the Bacillus pumilus subgroup B (DSMZ analysis). The major fatty acid was iso- $\mathrm{C}_{15: 0}$ with $48.8 \%$ of the total fatty acid content. Similar results were shown earlier for the closely related strains B. thioparans (77.3\% iso- $\left.C_{15: 0},[21]\right)$ and $B$. jeotgali $\left(49.3 \%\right.$ iso- $C_{15: 0}$ [56]). Detailed results of the fatty acid analysis are summarized in Table 1. 


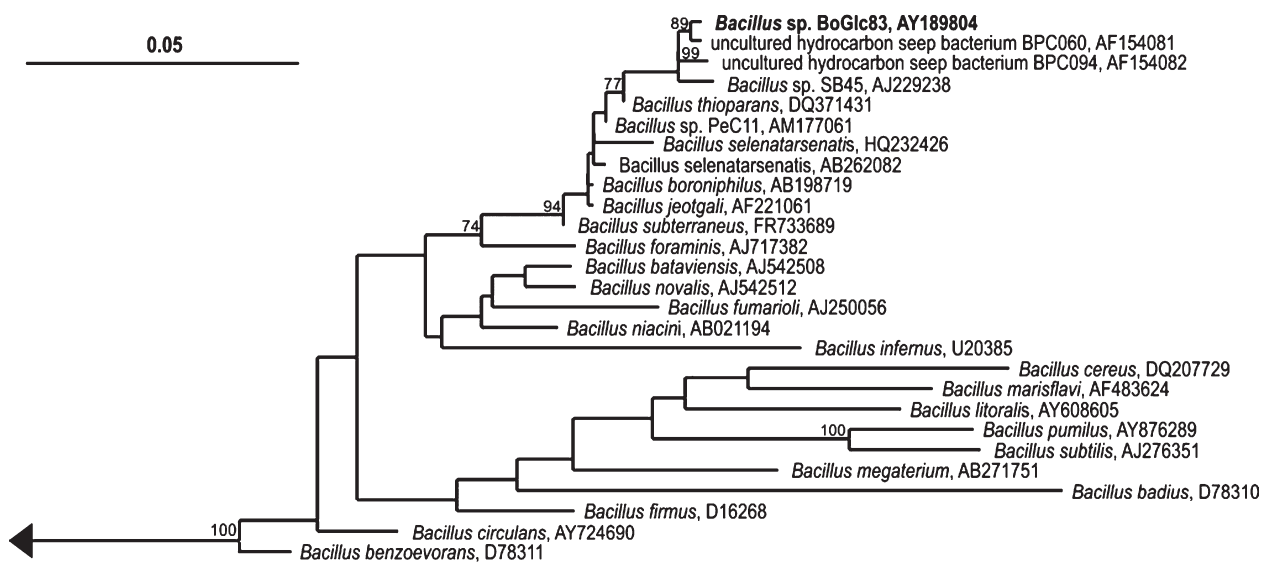

Fig. 1. Phylogenetic tree showing the position of Bacillus sp. strain BoGlc83 and closely related strains based on a 1488 bp long fragment of the $16 \mathrm{~S}$ rRNA gene. The tree was created using 1358 unambiguously aligned nucleotide positions and the maximum-likelihood method RAxML as implemented in ARB (http://www.arb-home.de, [15,41]). For nodes with bootstrap values higher than $70 \%$, the respective percentages are shown. Bar equals $5 \%$ estimated sequence divergence.

Table 1

Analysis of fatty acid composition of Bacillus sp. strain BoGlc83.

\begin{tabular}{|c|c|}
\hline \multicolumn{2}{|c|}{ Bacillus strain BoGlc83-composition of fatty acids \% } \\
\hline Fatty acid & Percentage \\
\hline$C_{10: 0}$ & 0.03 \\
\hline $\mathrm{i}-\mathrm{C}_{13: 0}$ & 0.26 \\
\hline ai- $C_{13: 0}$ & 0.05 \\
\hline $\mathrm{i}-\mathrm{C}_{14: 0}$ & 1.32 \\
\hline$C_{14: 0}$ & 0.84 \\
\hline $\mathrm{iF} \mathrm{C}_{15: 1}$ & 2.06 \\
\hline ai- $C_{15: 1}$ & 0.05 \\
\hline $\mathrm{i}-\mathrm{C}_{15: 0}$ & 48.81 \\
\hline ai- $C_{15: 0}$ & 10.93 \\
\hline $\mathrm{C}_{15: 0}$ & 0.08 \\
\hline $\mathrm{C}_{16: 1} \omega 7 \mathrm{c}$ alcohol & 0.99 \\
\hline $\mathrm{i}-\mathrm{C}_{16: 0}$ & 1.33 \\
\hline$C_{16: 1} \omega 11 c$ & 1.42 \\
\hline $\mathrm{C}_{16: 0}$ & 4.52 \\
\hline $\mathrm{i}-\mathrm{C}_{17: 1} \omega 10 \mathrm{c}$ & 7.32 \\
\hline ai- $C_{17: 1} \omega 9 \mathrm{c}$ & 0.18 \\
\hline $\mathrm{i}-\mathrm{C}_{17: 0}$ & 12.78 \\
\hline ai- $C_{17: 0}$ & 3.73 \\
\hline$C_{18: 1} \omega 9 c$ & 0.12 \\
\hline$C_{18: 1} \omega 7 \mathrm{c}$ & 0.07 \\
\hline$C_{18: 0}$ & 0.19 \\
\hline $\mathrm{i}-\mathrm{C}_{19: 0}$ & 0.11 \\
\hline Summed feature 1 & 0.06 \\
\hline Summed feature 3 & 0.47 \\
\hline Summed feature 4 & 2.29 \\
\hline
\end{tabular}

Analysis was done by the DSMZ identification service. Chromatographic peaks that could not be separated contained: Summed feature 1: i- $\mathrm{C}_{15: 1} \mathrm{H} / \mathrm{i}-\mathrm{C} 15: 1 \mathrm{I} / \mathrm{C}_{13: 0} 3 \mathrm{OH}$ Summed feature 3: $\mathrm{C}_{16: 1} \omega 7 \mathrm{c} / \mathrm{i}-\mathrm{C}_{15: 0} 2 \mathrm{OH}$; Summed feature 4: i- $\mathrm{C}_{17: 1} \mathrm{I} / \mathrm{ai}-\mathrm{C}_{17: 1} \mathrm{~B}$.

\section{Aerobic growth of strain BoGlc83}

If strain BoGlc83 was cultivated aerobically in freshwater medium with sulfate as sulfur source, growth was not always reproducible after transferring stationary cells to fresh medium and was found preferentially with complex growth media containing yeast extract or other undefined constituents. Aerobic growth was observed always for only 3-4 generations, i.e., one transfer after anaerobic cultivation; further aerobic cultivation yielded no further growth. Aerobic cultivation over more than 3-4 cell generations was possible in the presence of yeast extract $(0.05 \% \mathrm{w} / \mathrm{v})$. This growth-stimulating effect was further elucidated using freshwater medium with single amino acids or combinations of amino acids. Sulfur-containing amino acids caused substantially higher growth stimulation $\left(\Delta \mathrm{OD}_{578}=0.44 \pm 0.11\right.$ with $1 \mathrm{mM}$ L-methionine $+4 \mathrm{mM}$

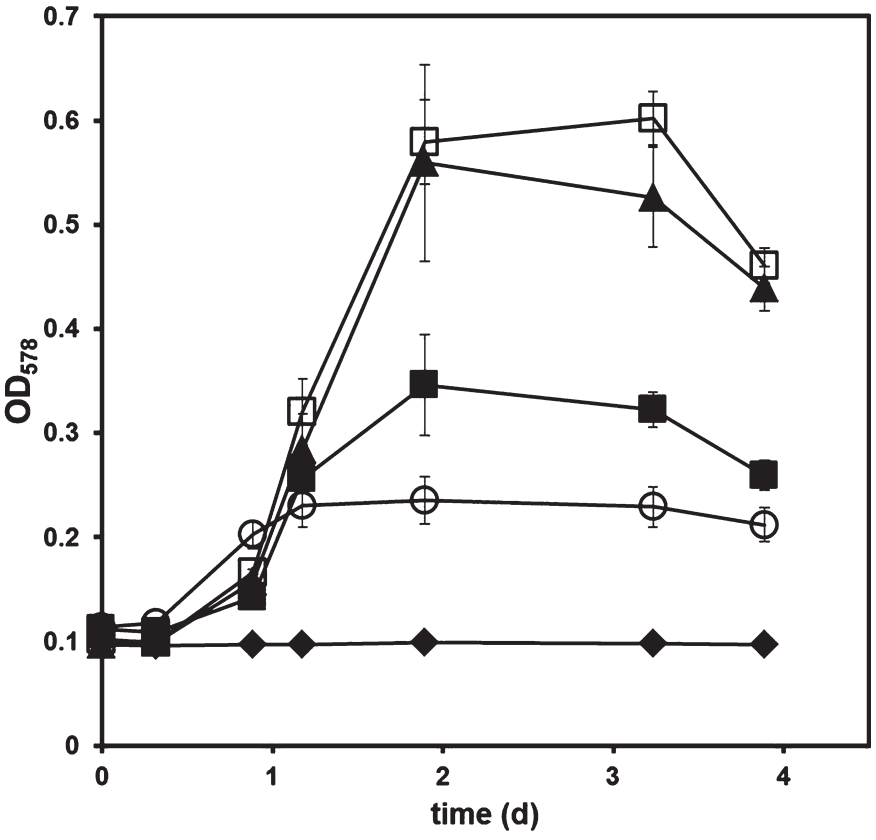

Fig. 2. Aerobic growth of strain BoGlc83 with different sulfur sources. Inocula were obtained by centrifugation of $500 \mu \mathrm{l}$ of anaerobic coculture with Methanospirillum hungatei. Pellets were washed three times in oxic minimal medium without sulfur source (filled diamonds) or in sulfide-reduced anoxic medium (filled squares). After the last wash, inocula were transferred to oxic minimal medium without sulfur source. A non-washed control was run in parallel (empty circles). In two additional experiments, sulfur-free washed inocula were transferred to media containing either $1.8 \mathrm{mM}$ thiosulfate (open squares) or $0.1 \% \mathrm{w} / \mathrm{v}$ elemental sulfur (filled triangles). Shown are mean values of $n=3$ of $\mathrm{OD}_{578} \pm$ standard deviation.

glucose) than other amino acids did (L-glutamine, $\Delta \mathrm{OD}_{578}=0.25$; glycine, leucine, alanine, asparagine $\left.\Delta \mathrm{OD}_{578}=0.15-0.19\right)$. Also glutathione stimulated growth substantially $\left(\Delta \mathrm{OD}_{578}=0.51\right.$ with $2 \mathrm{mM}$ glutathione). Obviously, the cells depended on a partly reduced sulfur source beyond the sodium sulfate that was present in the standard medium. As documented in Fig. 2, also partly reduced inorganic sulfur compounds such as thiosulfate or sulfur flower stimulated growth with sucrose in a similar manner as methionine did. As also shown in Fig. 2, small carry-overs of sulfide from reduced anaerobic precultures could stimulate growth of aerobic cultures. 


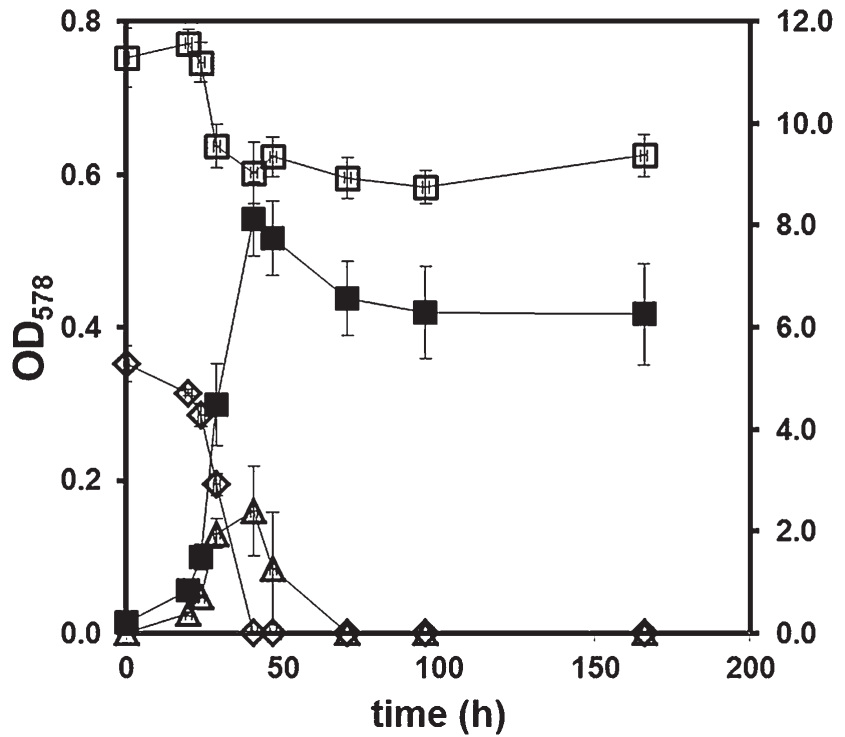

Fig. 3. Aerobic growth of strain BoGlc 83 with $5 \mathrm{mM}$ glucose plus $10 \mathrm{mM}$ thiosulfate. Shown are optical densities at $578 \mathrm{~nm}$ (filled squares), glucose concentrations (empty diamonds), acetate concentrations (empty triangles), and thiosulfate concentrations (empty squares). $N=3, \pm$ standard deviation.

Growth stimulation by thiosulfate with glucose as main energy source required at least $2 \mathrm{mM}$ thiosulfate to yield significant yield increases. In the presence of $4 \mathrm{mM}$ glucose, the thiosulfate-specific growth stimulation was higher than with $2 \mathrm{mM}$ glucose; higher thiosulfate additions $(4 \mathrm{mM}, 10 \mathrm{mM})$ did not stimulate glucosedependent growth any further. Addition of thiosulfate stimulated glucose consumption also in dense suspensions of resting cells (results not shown).

Thiosulfate was consumed together with glucose in aerobic cell suspensions at about a 1:1 stoichiometry. These cell suspensions were continuously sparged with air and the emitted gas was passed through a vessel containing cupric chloride solution. Formation of a brown precipitate in this vessel indicated the formation of hydrogen sulfide. Sulfate or sulfite could not be detected.

In growing batch cultures, thiosulfate was consumed incompletely during the exponential growth phase (Fig. 3). From an average of $11.3 \mathrm{mM}$ thiosulfate added to triplicate cultures, $9.4 \mathrm{mM}$ was still present at the end of growth (Fig. 3). Elemental sulfur could be detected in the cultures at an average concentration of $4.9 \mathrm{mM}$. Assuming that $1 \mathrm{~mol}$ of thiosulfate could be converted to $2 \mathrm{~mol}$ of elemental sulfur, this sulfur concentration approximately accounts for the $1.9 \mathrm{mM}$ thiosulfate consumed.

Aerobic growth was possible between $\mathrm{pH} 6.5$ and 8.5, with an optimum at $\mathrm{pH} 7.0-7.5$. No growth was found at $\mathrm{pH} 5.5$ and 9.5 (Table 4). Under optimal conditions at $\mathrm{pH} 7.2$, growth was comparably slow with $\mu=0.16-0.19 \mathrm{~h}^{-1}\left(t_{d} 3.7-4 \mathrm{~h}\right)$. The glucose-specific growth yield increased linearly in the range of $0-1.5 \mathrm{mM}$ glucose; at higher glucose concentrations, the increase was not proportional to the available substrate (Fig. 4). The molar growth yield was $57.8 \pm 1.3 \mathrm{~g}$ dry cell mass per mol glucose dissimilated. Several other sugars (fructose, galactose, mannose, lactose, maltose, sucrose) were utilized with similar growth efficiencies. Besides sugars, also acetate, citrate, fumarate, gluconate, lactate, pyruvate, or succinate were used as substrates for aerobic growth. There was no growth with single amino acids or combinations of different amino acids nor with monovalent alcohols. A list of substrates utilized or not utilized is found in the species description at the end of this paper. Several characteristics of strain BoGlc83 and its closest relatives are summarized in Table 4.

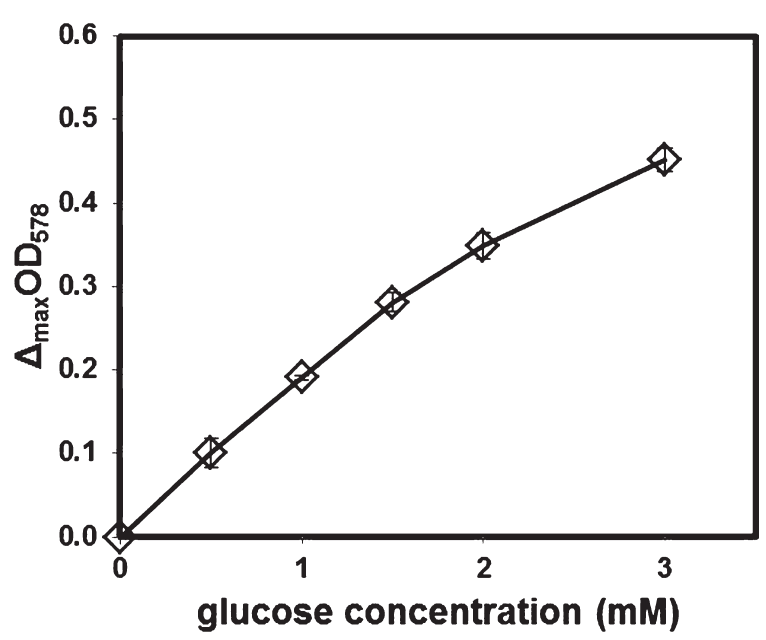

Fig. 4. Influence of glucose concentration on maximal optical densities reached by cultures of strain BoGlc83 grown in oxic minimal medium. Average maximal changes of $\mathrm{OD}_{578}$ of three independent cultures \pm standard deviation are presented. Some error bars are smaller than symbol size.

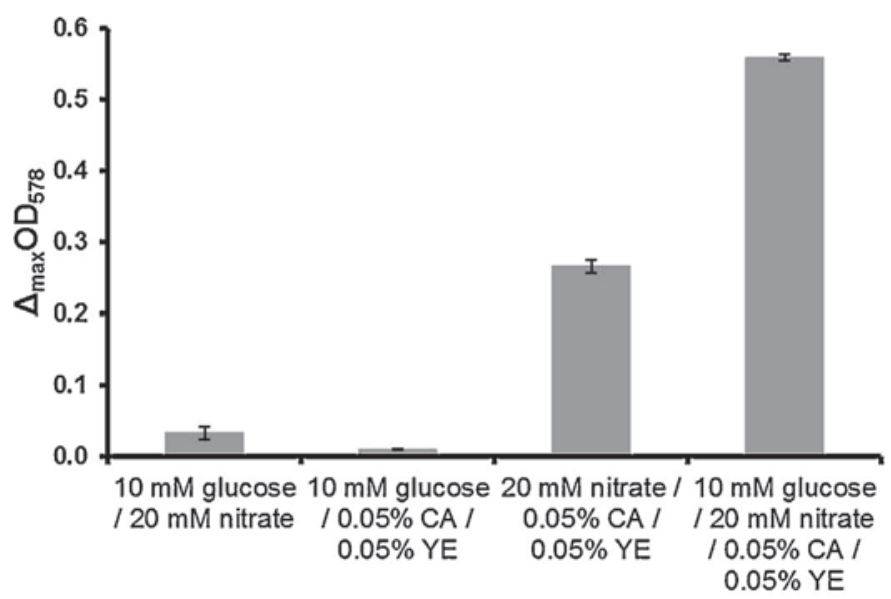

Fig. 5. Highest maximal changes of optical densities at $578 \mathrm{~nm}$ reached by cultures of strain BoGlc83 during anaerobic growth in non-reducing medium with different combinations of glucose, nitrate, casamino acids (CA), and yeast extract (YE). Mean values of three independent cultures \pm standard deviation after 5 days of incubation.

\section{Anaerobic growth in non-reducing medium}

In anoxic, non-reduced medium, strain BoGlc83 grew with glucose plus nitrate in the presence of $0.05 \%$ casamino acids and $0.05 \%$ yeast extract as supplements (Fig. 5). Growth was possible also with casamino acids, yeast extract, and tryptone as sole sources of carbon and energy respectively and with nitrate as an electron acceptor. However, growth on glucose plus nitrate was poor if no complex supplements were present (Fig. 5). Therefore, growth was tested both in the presence and absence of glucose. As shown in Fig. 5, glucose in addition to casamino acids, yeast extract, and nitrate yielded much higher optical densities than controls without glucose addition. Thus, strain BoGlc83 can oxidize glucose anaerobically with nitrate as electron acceptor in the presence of complex medium additions. For further characterization of nitrate reduction by strain BoGlc83, sulfate ( $2 \mathrm{mM}$ ) was added as a sulfur source. Of $20 \mathrm{mM}$ nitrate initially added to the medium, an average of $10.2 \mathrm{mM}$ nitrite was produced, and $3.9 \mathrm{mM}$ nitrate and $3.9 \mathrm{mM}$ glucose were still present at the end of growth. Oxidation of glucose was incomplete even though nitrate was still present, indicating that the accumulated nitrite inhibited further growth. Acetate $(5.9 \mathrm{mM})$ and lactate $(2.8 \mathrm{mM})$ were formed as further products. Similar results were 


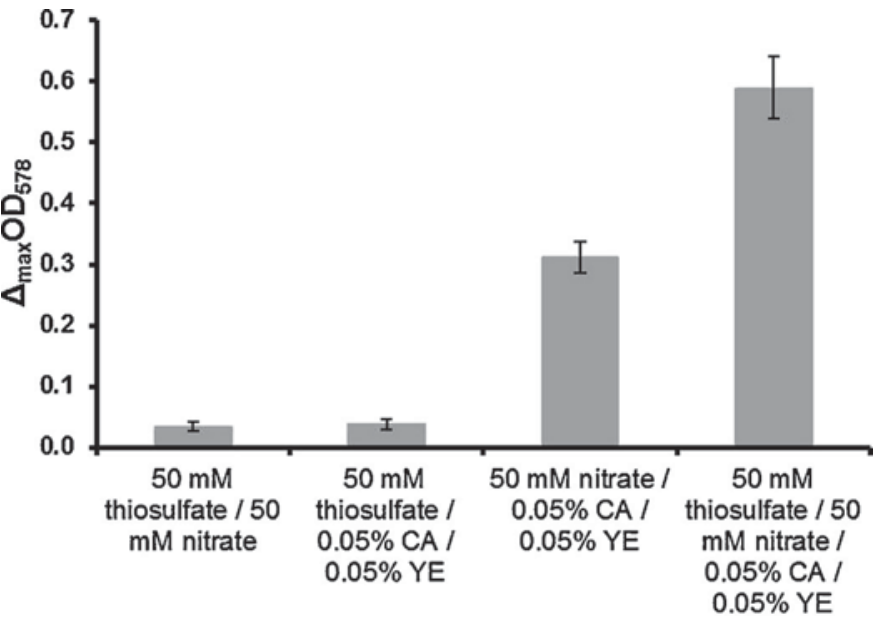

Fig. 6. Highest maximal changes of optical densities at $578 \mathrm{~nm}$ reached by cultures of strain BoGlc83 during anaerobic growth in non-reducing medium with different combinations of thiosulfate, nitrate, casamino acids (CA), and yeast extract (YE). Mean values of three independent cultures \pm standard deviation after 22 days of incubation.

obtained in cultures with $2 \mathrm{mM}$ thiosulfate as sulfur source (not shown). However, as mentioned above, under these conditions sulfur was most likely assimilated from organic sources in the complex supplements. In a control experiment, glucose was omitted and $1 \%$ casamino acids as carbon and energy source were added in the presence of $20 \mathrm{mM}$ nitrate and $2 \mathrm{mM}$ sulfate as sulfur source. After growth ended in three independent cultures, cultures with sulfate as sulfur source contained $9.4 \mathrm{mM}$ nitrite, while $17.2 \mathrm{mM}$ nitrite was still present in cultures with $2 \mathrm{mM}$ thiosulfate. Nitrate was completely consumed in both cases.

We also tested for possible use of thiosulfate as an energy source. Strain BoGlc83 was cultivated with $50 \mathrm{mM}$ thiosulfate, $50 \mathrm{mM}$ nitrate, $0.05 \%$ casamino acids, and $0.05 \%$ yeast extract (Fig. 6 ) Control cultures contained either no complex supplements, no thiosulfate, or no nitrate (Fig. 6). Cultures without casamino acids and yeast extract did not grow, whereas all cultures containing these complex supplements and nitrate grew well and reached stationary phase after $76 \mathrm{~h}$ (average $\Delta_{\max } \mathrm{OD}_{578}=0.31$, Fig. 6). Optical densities in cultures with thiosulfate in addition to casamino acids, yeast extract, and nitrate increased further, and the cultures reached stationary phase after 22 days (average $\Delta_{\max } \mathrm{OD}_{578}=0.59$, Fig. 6). Formation of a white precipitate was observed in these cultures suggestive of production of elemental sulfur. The concentration of elemental sulfur in these cultures was $10.1 \mathrm{mM}$ $( \pm 2.4 \mathrm{mM})$, while $4.1 \mathrm{mM}$ thiosulfate was consumed as judged by colorimetric assays.

\section{Anaerobic growth in reducing medium}

Strain BoGlc83 did not grow in reducing medium in pure culture $\left(\Delta \mathrm{OD}_{578}\right.$ below 0.1$)$, neither with glucose nor with pyruvate added separately to the medium. However, cultures were metabolically active under these conditions, as glucose or pyruvate was slowly converted to lactate and acetate (Table 2). If both glucose and pyruvate were supplied in the presence of $0.05 \%$ casamino acids and $0.05 \%$ yeast extract, cultures grew to an average $\Delta_{\max } \mathrm{OD}_{578}$ of 0.19 (Fig. 7). Weak growth was found also in the absence of casamino acids and yeast extract, yet to a much lower extent than in cultures with these supplements (data not shown). Fermentation products were lactate, succinate, acetate, and formate (Tables 2 and 3). Ethanol was never produced by strain BoGlc83. However, the closely related $B$. jeotgali and Bacillus sp. PeC11 produced significant amounts of ethanol during growth on glucose

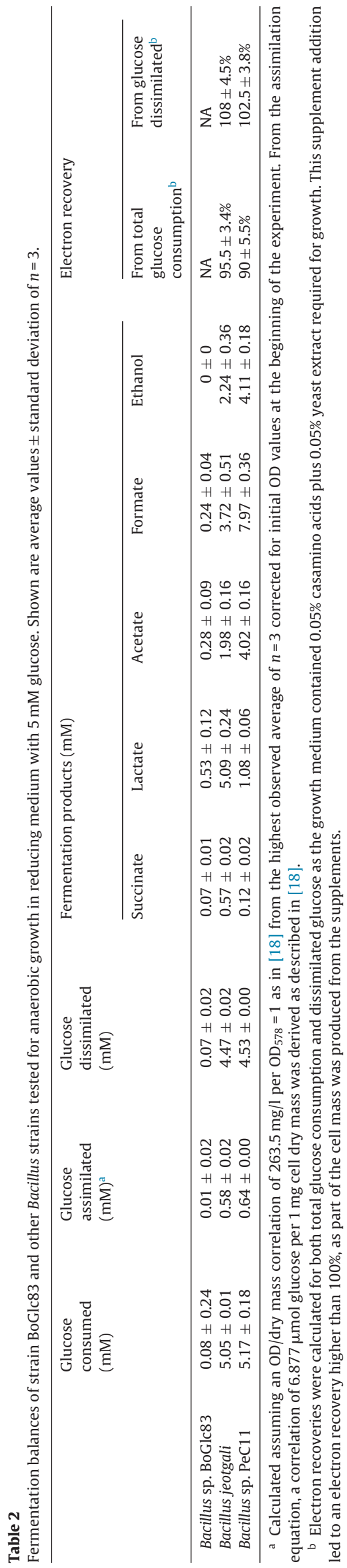



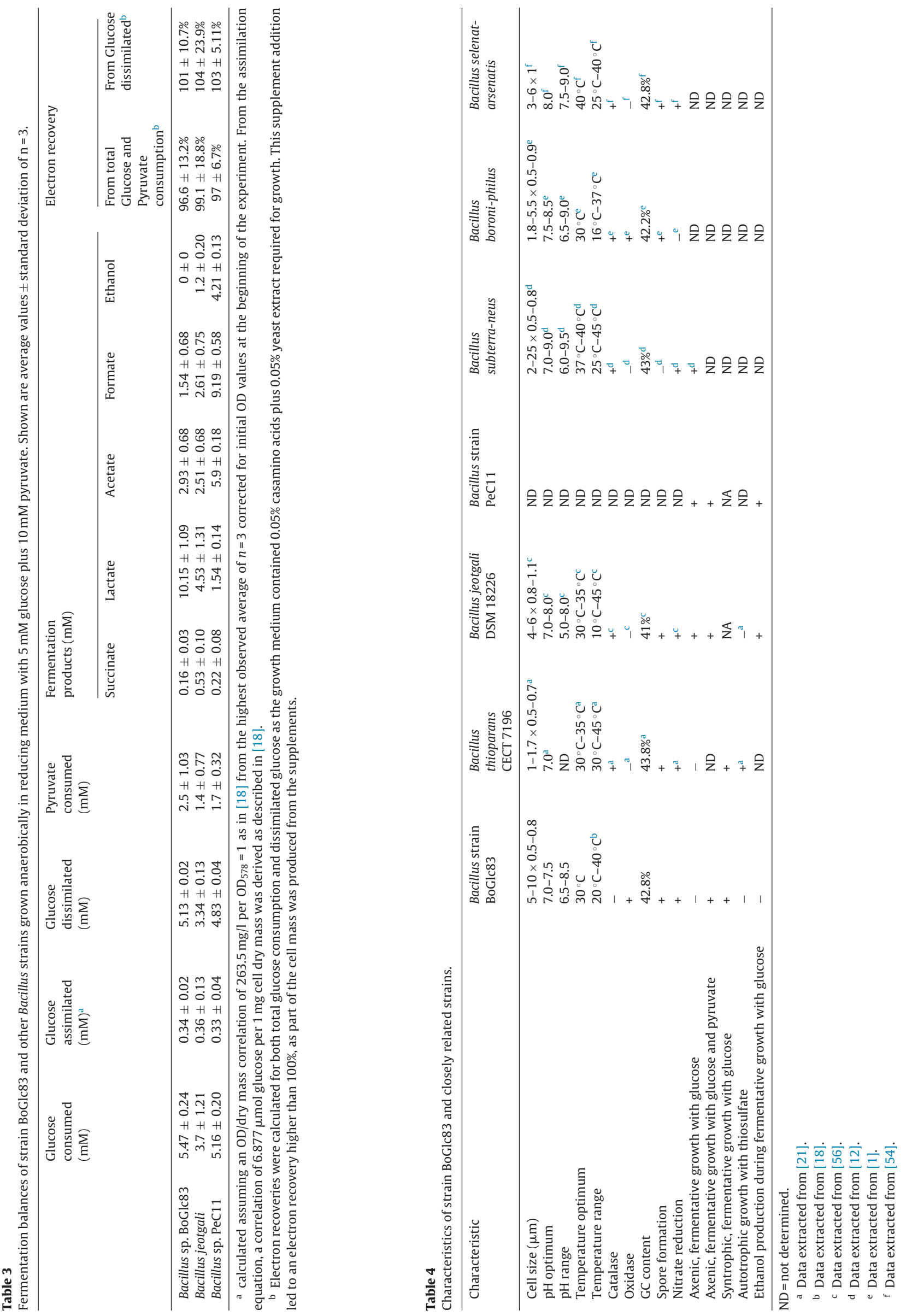


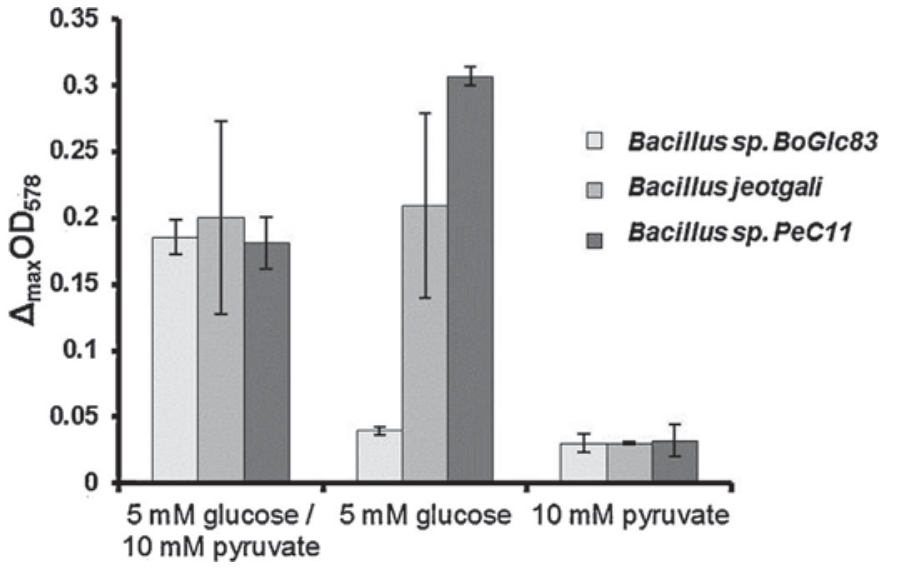

Fig. 7. Anaerobic growth of strain BoGlc83, Bacillus jeotgali, and Bacillus sp. PeC11 in reducing medium. Media contained both $0.05 \%$ casamino acids and $0.05 \%$ yeast extract and either $5 \mathrm{mM}$ glucose plus $10 \mathrm{mM}$ pyruvate, $5 \mathrm{mM}$ glucose, or $10 \mathrm{mM}$ pyruvate. Shown are mean values of the highest changes of optical densities at $578 \mathrm{~nm}$ of three independent cultures \pm standard deviation after $135 \mathrm{~h}$ of incubation.

(Tables 2-4), and were also able to grow without added pyruvate (Fig. 7). The pattern of fermentation products during growth with glucose plus pyruvate differed greatly between the three strains (Table 3). The major fermentation product of strain BoGlc83 was lactate, with minor amounts of acetate and formate. Also B. jeotgali produced mainly lactate, but also formate, acetate, ethanol, and succinate (Table 3). In contrast, Bacillus sp. strain PeC11 produced mainly formate, acetate, and ethanol, together with minor amounts of lactate and succinate (Table 3). None of these strains tested grew with $10 \mathrm{mM}$ pyruvate alone.

\section{Syntrophic growth}

Anaerobic growth under reducing conditions with glucose in the presence of M. hungatei was shown earlier for Bacillus sp. BoGlc83 [18]. We also tested other closely related Bacillus strains for syntrophic growth. Of the tested B. megaterium, B. thioparans, B. jeotgali, and Bacillus sp. Pec11, only $B$. thioparans was able to grow in this medium with glucose in the presence of $M$. hungatei after an incubation time of approximately 1 month, while axenic growth of $B$. thioparans with glucose was not possible (Table 4). B. megaterium did not grow at all under these conditions and B.jeotgali and Bacillus sp. PeC11 reached stationary phase already after 7 days as both are able to grow with glucose without a methanogenic partner. There was no indication of a fermentation product shift by the presence of the methanogenic partner.

\section{Discussion}

The bacterial strain described in this study, strain BoGlc83, was originally isolated as a numerically predominant utilizer of glucose and other sugars in the sediment of Lake Constance, Germany. Anaerobic growth was possible only in the presence of formateor hydrogen-utilizing methanogenic partners. Later, it turned out that this bacterium grouped with the genus Bacillus on the basis of 16S rRNA gene sequence data, and that it was also able to grow aerobically. However, as documented in the present study, aerobic growth was not easy to reproduce on standard media but required partly reduced sulfur compounds, either organic or inorganic ones, for reproducible aerobic growth. Sulfur, thiosulfate, or sulfite could serve as sulfur source under these conditions. Nonetheless, the requirement for such partly reduced sulfur compounds was comparably high, in the range of $2 \mathrm{mM}$, far more than the amount of sulfur required for assimilation only (which would be in the range of $20-50 \mu \mathrm{M} S$ with the cell densities reached, assuming a sulfur content of cell dry matter of about $1 \%$ ). In aerobic cultures, thiosulfate was converted to elemental sulfur especially during the exponential growth phase, indicating that thiosulfate can serve as an additional electron acceptor when oxygen becomes limiting due to the increasing cell density. In dense cell suspensions of aerobically grown cells of strain BoGlc83, consumption of thiosulfate was even more pronounced, thus supporting the hypothesis that the cells become oxygen-limited with increasing cell density, even if the cell suspensions are vigorously sparged with air. Unfortunately, elemental sulfur was not measured in cell suspension experiments. It is known from other thiosulfate-metabolizing bacteria that elemental sulfur and sulfite are products of thiosulfate cleavage [3]. In strain BoGlc83, it appears that $1 \mathrm{~mol}$ of thiosulfate is converted to 2 mol of elemental sulfur according to the measured stoichiometry. Moreover, sulfite or sulfate could never be detected, neither after aerobic nor after anaerobic growth.

Strain BoGlc83 grew optimally aerobically with doubling times of 3-4 h. In standard enrichment cultures with sugars as substrates, it would always be outcompeted by faster aerobic bacteria. The same applies for cultivation under anoxic conditions $\left(t_{d}>24 \mathrm{~h}\right)$ : classical sugar-fermenting bacteria such as Clostridium spp. would outcompete it very quickly although such bacteria were found in our sediment only at substantially lower numbers [18]. Isolation of this novel bacterium was possible only in direct dilution series in the presence of a background lawn of methanogenic partners. Nonetheless, the fact that this bacterium appears to be a dominant sugar utilizer in the lake sediment studied indicates that under the conditions prevailing there this type of organism has a clear advantage over others, e.g., by optimal ATP generation in syntrophic cooperation [31].

Strain BoGlc83 can grow auxotrophically in anoxic, nonreducing medium by nitrate respiration on glucose, with casamino acids, yeast extract, tryptone, or thiosulfate present. However, nitrate reduction was incomplete in batch cultures and most of the nitrate present in the cultures accumulated as nitrite. Nitrate reduction is rather common in Bacillus strains, however, oxidation of thiosulfate as an electron source for nitrate reduction within the genus Bacillus has so far been described only for $B$. thioparans $[21,35]$. Yet, the type of metabolism is already known for other bacteria like Thiobacillus denitrificans [11]. In our hands, strain BoGlc83 did not grow lithoautotrophically with thiosulfate as this was shown earlier for B. thioparans [21]. Yet, during auxotrophic growth in the presence of yeast extract and casamino acids, optical densities increased and elemental sulfur was detected in the cultures while part of the thiosulfate was consumed. Formation of a white precipitate was observed in these cultures which could be insoluble elemental sulfur and therefore makes it difficult to judge whether the observed increase in turbidity is growth related. However, cells are obviously metabolically active under these conditions. Therefore, it is likely that strain BoGlc83 uses thiosulfate as an electron acceptor, e.g. if nitrite concentrations in anaerobic cultures are too high to allow further nitrate reduction. In cultures with thiosulfate, casamino acids and yeast extract no growth was observed which shows that nitrate is essential and thiosulfate addition alone cannot support growth. But the fact that during both aerobic and anaerobic growth $1 \mathrm{~mol}$ of thiosulfate is converted to $2 \mathrm{~mol}$ of elemental sulfur indicates that thiosulfate serves as electron acceptor rather than as electron donor for strain BoGlc83. Thiosulfate oxidation as in B. thioparans or Thiobacillus intermedius would yield sulfite and sulfate as intermediates or end products $[3,21]$, which could never be detected in cultures of strain BoGlc83.

If grown anaerobically under reducing conditions, strain BoGlc83 was unable to grow on glucose without a syntrophic 
partner at first, even though accumulation of fermentation products could be observed in the medium. However, if pyruvate and supplements were added strain BoGlc83 grew by mixed-acid fermentation. Limited growth was possible also if no supplements but only glucose and pyruvate were added. Also Bacillus subtilis can grow by fermentation of glucose in anoxic, non-reduced Spizizen's medium amended with amino acid mixtures, however, addition of pyruvate to cultures with glucose augmented growth significantly [19]. It was concluded that pyruvate might serve as a stimulating agent that triggers expression of genes required for mixed acid fermentation, as the intracellular pyruvate pool might be too small to initiate expression of genes required for fermentation. Also, pyruvate was discussed as a precursor of certain amino acids that cannot be synthesized by B. subtilis [19]. Similar conclusions were drawn before from observations made with the methanogenic archaeon Methanosarcina barkeri [17]. Here, a mutant that lacks ech-hydrogenase could not grow on methanol. Upon addition of pyruvate to the medium, the ability to grow was restored, and it was concluded that the ech-hydrogenase provides the cells with reduced ferredoxin to secure pyruvate synthesis from acetyl-CoA. Pyruvate in turn could then serve as a precursor for biosynthesis [17].

In the case of strain BoGlc83, none of the latter conclusions of gene expression triggered by pyruvate or deficiency in biosynthesis pathways can explain the growth-supporting effect of pyruvate. First, fermentation pathways are expressed if strain BoGlc83 is incubated in pure culture on glucose, as indicated by the production of fermentation products; the strain just does not grow measurably. Second, even in the presence of casamino acids and yeast extract, no growth is observed on glucose alone, indicating that amino acid synthesis deficiencies are not a suitable explanation for the inability of the strain to grow under these conditions. Moreover, the strain grows well in the presence of a methanogenic partner without addition of supplements. Yet, it is possible that strain BoGlc83 lacks uptake systems for certain amino acids but not for pyruvate, meaning that these amino acids could only be synthesized if high amounts of pyruvate are available. Such a situation could occur during syntrophic growth, i.e. if pyruvate does not need to be reduced to lactate or succinate to regenerate electron carriers. Instead, during syntrophic growth, a reversed electron transport system in strain BoGlc83 was suspected earlier to be responsible for the regeneration of NADH to NAD with a low-potential electron acceptor, such that electrons finally could be transferred to protons or to protons plus carbon dioxide, to form hydrogen or formate [18]. In the previously published article, we reported specific activities for formate dehydrogenase with benzyl viologen as electron acceptor that were about 7 fold higher than the specific activity for hydrogenase. It was further concluded that formate might be the major electron carrier mediating interspecies hydrogen transfer, even though a small part of electrons from glucose oxidation might also be released as hydrogen. This was supported by the fact that strain BoGlc83 did not grow well in the presence of the hydrogen-only consuming Methanobrevibacter arboriphilus [18]. Further indications that formate acts as an electron carrier to its methanogenic partner are presented in this paper. While in syntrophic cocultures of strain BoGlc 83 and the hydrogen and formate-consuming $M$. hungatei only traces of formate were detected [18], formate was produced in substantial amounts $(1.54 \mathrm{mM})$ during growth in pure culture on $5 \mathrm{mM}$ glucose plus $10 \mathrm{mM}$ pyruvate, indicating that the pathway of formate production is expressed and could serve as a major electron sink during syntrophic growth. Formate production in the two other Bacillus strains tested in the present study was even higher, $2.6 \mathrm{mM}$ for B. jeotgali and $9.2 \mathrm{mM}$ for Bacillus sp. strain $\mathrm{PeC} 11$, which was also shown earlier for strain PeC11 under anaerobic, non-reducing conditions [10]. Apparently, the Bacillus strains B. jeotgali and Bacillus sp. strain PeC11 do not need pyruvate to initiate fermentative growth on glucose. However, the fermentation patterns differ between the different Bacillus spp., and syntrophic growth of those strains could not be observed yet as the strains outgrow the slow-growing $M$. hungatei when incubated in medium with glucose. The fact that all three strains can produce formate up to several millimolar concentrations also suggests that the inability of strain BoGlc83 to grow with glucose alone cannot be explained by growth inhibition through formate.

During growth on glucose and pyruvate, lactate is the major fermentation product in strain BoGlc83, in contrast to B. jeotgali and Bacillus sp. PeC11 which grow on glucose without addition of pyruvate. This indicates that the pathway of lactate formation from pyruvate is strongly expressed in strain BoGlc83, which in turn could imply that pyruvate is rapidly consumed inside the cell by lactate dehydrogenase. Consequently, the size of the intracellular pyruvate pool might be insufficient to synthesize essential amino acids which possibly cannot be taken up by the cell though present in the medium. Externally added pyruvate might help to compensate for the intracellular pyruvate loss through lactate production, which would explain why strain BoGlc83 can grow under these conditions.

According to the 16S rRNA gene sequence analysis, strain BoGlc83 and similar strains isolated with it have to be assigned to the genus Bacillus which contains mainly strictly aerobic, Grampositive spore-forming bacteria. Several Bacillus species can also grow anaerobically by a fermentative metabolism, e.g., $B$. subtilis [19], B. cereus, B. thuringiensis, B. licheniformis, B. coagulans, $B$. polymyxa, B. macerans, B. alvei, B. laterosporus, B. larvae, B. popilliae, and $B$. lentimorbus [35]. Nonetheless, syntrophic cooperation with methanogenic partners has not been described so far for any Bacillus species. The closest relative according to our initial sequence analysis [18], B. jeotgali, was described as a facultatively aerobic bacterium and was isolated from fermenting seafood [56]. According to a detailed analysis of 16S rRNA gene sequences of more than 2600 Bacillus strains, our isolates fall into cluster 9, together with several so far non-described strains [23]. Most of these strains were found as numerically dominant representatives of the cultivable community in Dutch grassland soils [8], anoxic rice paddy soil [4], pasture soil [34], farm soil [47], or contaminated gelatine preparations [5]. Obviously, representatives of cluster 9 are widespread in nature and rather numerous in various environments.

Analysis of the 16S rRNA gene sequence of strain BoGlc83 showed that the strain is closely related to other described species. Even though, a threshold value of $97 \%$ sequence similarity has been commonly used since 20 years for the description of new species, a less conservative threshold value of $98.7 \%$ was postulated in recent years $[28,38,39,55]$. The 165 rRNA gene sequence similarity of strain BoGlc83 and the sequence of $B$. thioparans is $98.91 \%$, the sequences of all other closely related and taxonomically described strains have a similarity below the threshold value of $98.7 \%$. Therefore, DNA-DNA hybridization experiments were done only with strain BoGlc83 and B. thioparans. The determined DNA-DNA similarity of maximally $25.5 \%$ taxonomically differentiates strain BoGlc83 and B. thioparans and thus establishes Bacillus strain BoGlc83 as new species.

\section{Description of Bacillus stamsii sp. nov.}

Bacillus stamsii spec. nov. (stam'si.i. N.L. gen. n., honoring Alfons J. M. Stams, a Dutch microbiologist who has contributed essentially to our understanding of syntrophic microbial associations).

Facultatively aerobic, Gram-positive spore-forming bacterium. Catalase-negative, oxidase positive after aerobic growth. Cells rodshaped, $0.5 \times 5 \mu \mathrm{m}$ in size, with subterminal to terminal oval spores. Motile. Aerobic growth requires partly reduced sulfur sources for assimilation (sulfur flower, thiosulfate, sulfide, sulfite, 
organic sulfur compounds). Aerobically, fructose, galactose, glucose, mannose, ribose, maltose, sucrose, starch, glycerol, acetate, citrate, fumarate, gluconate, lactate, malate, pyruvate, succinate are used for growth. No growth with arabinose, sorbose, lactose, arabitol, 1-butanol, ethanol, methanol, mannitol, salicin, benzoate, crotonate, formate, glycolate, 2 -oxoglutarate, oxalate, propionate, tartrate, cholate. No growth with single amino acids or with glutathione. Optimal growth at $30^{\circ} \mathrm{C}$, at $\mathrm{pH} 7-7.5$. Growth between $\mathrm{pH}$ 6.5 and 8.5. Aerobic growth is possible also in complex media like LB medium containing $10 \mathrm{mg} / \mathrm{l}$ of $\mathrm{MnSO}_{4}$, yet not always reproducible.

During anaerobic growth in non-reducing medium with glucose or casamino acids, nitrate but not nitrite can serve as external electron acceptor. Casamino acids, tryptone, and yeast extract also support growth during nitrate respiration. Thiosulfate can serve as an alternative electron acceptor during nitrate respiration. No autotrophic growth with thiosulfate as electron donor and nitrate as electron acceptor.

Anaerobic growth in sulfide-reduced medium depends on the presence of a $\mathrm{H}_{2}$ or formate-scavenging partner organism. Glucose, fructose, or maltose used as substrates under these conditions. Alternatively, anaerobic growth in reducing medium without a partner organism is possible in the presence of glucose plus pyruvate. Under these conditions growth is stimulated by but not dependent on addition of $0.05 \%$ casamino acids and $0.05 \%$ yeast extract.

The $\mathrm{G}+\mathrm{C}$ content of strain BoGlc83 is $42.8 \% \mathrm{G}+\mathrm{C}$. Respiratory quinones are menaquinone- 6 and menaquinone- 7 . The predominant fatty acid is iso- $\mathrm{C}_{15: 0}$.

The type strain BoGlc83 (DSM $19598=$ JCM 30025) was isolated from littoral sediment of Lake Constance in May 2002.

\section{Acknowledgements}

This study was supported by a grant (Schi 180/10) of the Deutsche Forschungsgemeinschaft, Bonn-Bad Godesberg, and by research funds of the Universität Konstanz. We thank Antje Wiese for technical help.

\section{References}

[1] Ahmed, I., Yokota, A., Fujiwara, T. (2007) A novel highly boron tolerant bacterium, Bacillus boroniphilus sp, nov, isolated from soil, that requires boron for its growth. Extremophiles 11, 217-224.

[2] Altschul, S.F., Gish, W., Miller, W., Myers, E.W., Lipman, D.J. (1990) Basic local alignment search tool. J. Mol. Biol. 215, 403-410.

[3] Charles, A.M. (1969) Mechanism of thiosulfate oxidation by Thiobacillus intermedius. Arch. Biochem. Biophys. 129, 124-130.

[4] Chin, K.-J., Hahn, D., Hengstmann, U., Liesack, W., Janssen, P.H. (1999) Characterization and identification of numerically abundant culturable bacteria from the anoxic bulk soil of rice paddy microcosms. Appl. Environ. Microbiol. 65, 5042-5049.

[5] De Clerck, E., De Vos, P. (2002) Study of the bacterial load in a gelatine production process focussed on Bacillus and related endosporeforming genera. Syst. Appl. Microbiol. 25, 611-617.

[6] Edwards, U., Rogall, T., Blöcker, H., Emde, M., Böttger, E.C. (1989) Isolation and direct complete nucleotide determination of entire genes. Characterization of a gene coding for $16 \mathrm{~S}$ ribosomal RNA. Nucleic Acids Res. 17, $7843-7853$.

[7] Euzéby, J. (2007) List of new names and new combinations previously effectively, but not validly, published. Int. J. Syst. Evol. Microbiol. 57, 1933-1934.

[8] Felske, A., Wolterink, A., van Lis, R., de Vos, W.M., Akkermans, A.D.L. (1999) Searching for predominant soil bacteria: 16S rDNA cloning versus strain cultivation. FEMS Microbiol. Ecol. 30, 137-145.

[9] Hall, T.A. (1999) BioEdit: a user-friendly biological sequence alignment editor and analysis program for Windows 95/98/NT. Nucl. Acids Symp. Ser. 41 95-98.

[10] Hobbie, S.N., Li, X., Basen, M., Stingl, U., Brune, A. (2012) Humic substancemediated $\mathrm{Fe}(\mathrm{III})$ reduction by a fermenting Bacillus strain from the alkaline gut of a humus-feeding scarab beetle larva. Syst. Appl. Microbiol. 35, $226-232$.

[11] Kuenen, J.G., Robertson, L.A., Tuovinen, O.H. (1991) The Genera Thiobacillus, Thiomicrospira and Thiosphaera, in: Balows, A., Trüper, H.G., Dworkin,
M., Harder, W., Schleifer, K.-H. (Eds.), The Prokaryotes, vol. 3, second edition, Springer, New York/Berlin/Heidelberg, pp. 2638-2657, chapter 138

[12] Kanso, S., Greene, A.C., Patel, B.K.C. (2002) Bacillus subterraneus sp. nov., an iron- and manganese-reducing bacterium from a deep subsurface Australian thermal aquifer. Int. J. Syst. Evol. Microbiol. 52, 869-874.

[13] Kim, O.S., Cho, Y.J., Lee, K., Yoon, S.H., Kim, M., Na, H., Park, S.C., Jeon, Y.S., Lee, J.H., Yi, H., Won, S., Chun, J. (2012) Introducing EzTaxon: a prokaryotic 16S rRNA Gene sequence database with phylotypes that represent uncultured species. Int. J. Syst. Evol. Microbiol. 62, 716-721.

[15] Ludwig, W., Strunk, O., Westram, R., Richter, L., Meier, H., Yadhukumar, Buchner, A., Lai, T., Steppi, S., Jobb, G., Förster, W., Brettske, I., Gerber, S., Ginhart, A.W., Gross, O., Grumann, S., Hermann, S., Jost, R., König, A., Liss, T., Lüssmann, R., May, M., Nonhoff, B., Reichel, B., Strehlow, R., Stamatakis, A., Stuckmann, N., Vilbig, A., Lenke, M., Ludwig, T., Bode, A., Schleifer, K.H. (2004) ARB: a software environment for sequence data. Nucleic Acids Res. 32 (4), 1363-1371.

[17] Meuer, J., Kuettner, H.C., Zhang, J.K., Hedderich, R., Metcalf, W.W. (2002) Genetic analysis of the archaeon Methanosarcina barkeri Fusaro reveals a central role for Ech hydrogenase and ferredoxin in methanogenesis and carbon fixation. PNAS 99 (8), 5632-5637.

[18] Müller, N., Griffin, B.M., Stingl, U., Schink, B. (2008) Dominant sugar utilizers in sediment of Lake Constance depend on syntrophic cooperation with methanogenic partner organisms. Environ. Microbiol. 10 (6), 1501-1511.

[19] Nakano, M.M., Dailly, Y.P., Zuber, P., Clark, D.P. (1997) Characterization of anaerobic fermentative growth of Bacillus subtilis: identification of fermentation end products and genes required for growth? J. Bacteriol. 179 (21), 6749-6755.

[20] Nor, Y.M., Tabatabai, M.A. (1975) Colorimetric determination of microgram quantities of thiosulfate and tetrathionate. Anal. Lett. 8 (8), 537-547.

[21] Pérez-Ibarra, B.M., Flores, M.E., Garcia-Varela, M. (2007) Isolation and characterization of Bacillus thioparus sp. nov., chemolithoautotrophic, thiosulfateoxidizing bacterium. FEMS Microbiol. Lett. 271 (2007), 289-296.

[23] Porwal, S., Lal, S., Cheema, S., Kalia, V.C. (2009) Phylogeny in aid of the present and novel microbial lineages: diversity in Bacillus. PLoS ONE 4 (2), e4438, Epub 2009 Feb 12.

[24] Pruesse, E., Peplies, J., Glöckner, F.O. (2012) SINA: accurate high-throughput multiple sequence alignment of ribosomal RNA genes. Bioinformatics 28 1823-1829.

[25] Quast, C., Pruesse, E., Yilmaz, P., Gerken, J., Schweer, T., Yarza, P., Peplies, J., Glöckner, F.O. (2013) The SILVA ribosomal RNA gene database project: improved data processing and web-based tools. Nucleic Acids Res. 41 (D1) D590-D596.

[28] Roselló-Móra, R. (2012) Towards a taxonomy of Bacteria and Archaea based on interactive and cumulative data repositories? Environ. Microbiol. 14 (2) 318-334.

[30] Schedel, M., Trüper, H.G. (1980) Anaerobic oxidation of thiosulfate and elemental sulfur in Thiobacillus denitrificans. Arch. Microbiol. 124, 205-210.

[31] Schink, B. (1997) Energetics of syntrophic cooperation in methanogenic cooperation. Microbiol. Mol. Biol. Rev. 61, 262-280.

[34] Schoenborn, L., Yates, P.S., Grinton, B.E., Hugenholtz, P., Janssen, P.H. (2004) Liquid serial dilution is inferior to solid media for isolation of cultures representative of the phylum-level diversity of soil bacteria. Appl. Environ. Microbiol. 70, 4363-4366.

[35] Slepecky, R.A., Hemphill, H.E. (1991) The genus Bacillus - nonmedical, in: Balows, A., Trüper, H.G., Dworkin, M., Harder, W., Schleifer, K.-H. (Eds.), The Prokaryotes, vol. 2, second edition, Springer, New York/Berlin/Heidelberg, pp. 1663-1696, chapter 76 .

[38] Stackebrandt, E., Goebel, B.M. (1994) Taxonomic note: a place for DNA-DNA reassociation and $16 \mathrm{~S}$ rRNA sequence analysis in the present species definition in bacteriology. Int. J. Syst. Bacteriol. 44 (4), 846-849.

[39] Stackebrandt, E., Ebers, J. (2006) Taxonomic parameters revisited: tarnished gold standards. Microbiol. Today 8, 6-9.

[41] Stamatakis, A. (2014) RAxML version 8: a tool for phylogenetic analysis and post-analysis of large phylogenies. Bioinformatics, http://dx.doi.org/10.1093/ bioinformatics/btu033

[43] Tabatabai, M.A. (1974) Determination of sulfate in water samples. Sulphur Inst. J. 10, 11-13.

[47] Tzeneva, V.A., Li, Y., Felske, A.D.M., de Vos, W.M., Akkermans, A.D.L. Vaughan, E.E., Smidt, H. (2004) Development and application of a selective PCR-denaturing gradient gel electrophoresis approach to detect a recently cultivated Bacillus group predominant in soil. Appl. Environ. Microbiol. 70, 5801-5809.

[49] Wayne, L.G., Brenner, D.J., Colwell, R.R., Grimont, P.A.D., Kandler, O., Krichevsky, M.I., Moore, L.H., Moore, W.E.C., Murray, R.G.E., Stackebrandt, E., Starr, M.P., Trüper, H.G. (1987) Report of the ad hoc committee on reconciliation of approaches to bacterial systematics. Int. J. Syst. Bacteriol. 37, 463-464.

[50] Weisburg, W.G., Barns, S.M., Pelletier, D.A., Lane, D.J. (1991)16S ribosomal DNA amplification for phylogenetic study. J. Bacteriol. 173, 697-703.

[51] Widdel, F., Kohring, G.W., Mayer, F. (1983) Studies on dissimilatory sulfatereducing bacteria that decompose fatty acids.III. Characterization of the filamentous gliding Desulfonema limicola gen. nov. sp. nov., and Desulfonema magna sp. nov. Arch. Microbiol. 134, 286-294.

[52] Widdel, F., Bak, F. (1992) Gram-negative mesophilic sulfate-reducing bacteria. In: Balows, A., Trüper, H.G., Dworkin, M., Harder, W., Schleifer, K.H. (Eds.), The Prokaryotes, Springer Verlag, Berlin, pp. 3352-3378.

[53] Widdel, F., Pfennig, N. (1981) Studies on dissimilatory sulfate-reducing bacteria that decompose fatty acids. I. Isolation of a new sulfate-reducer enriched with 
acetate from saline environments. Description of Desulfobacter postgatei gen. nov. sp. nov. Arch. Microbiol. 129, 395-400.

[54] Yamamura, S., Yamashita, M., Fujimoto, N., Kuroda, M., Kashiwa, M., Sei, K., Fujita, M., Ike, M. (2007) Bacillus selenatarsenatis sp. nov., a selenate- and arsenate-reducing bacterium isolated from the effluent drain of a glass-manufacturing plant. Int. J. Syst. Evol. Microbiol. 57, 1060-1064.
[55] Yarza, P., Yilmaz, P., Pruesse, E., Glöckner, F.O., Ludwig, W., Schleifer, K.H., Whitman, W.B., Euzéby, J., Amann, R., Roselló-Móra, R. (2014) Uniting the classification of cultured and uncultured bacteria and archaea using 16S rRNA gene sequences. Nat. Rev. Microbiol. 12 (9), 635-645.

[56] Yoon, J.H., Kang, S.S., Lee, K.C., Kho, Y.H., Choi, S.H., Kang, K.H., Park, Y.H. (2001) Bacillus jeotgali sp. nov., isolated from jeotgal. Korean traditional fermented seafood. Int. J. Syst. Evol. Microbiol. 51 (3), 1087-1092. 